\title{
The Sydney tar ponds: lessons learned from Canada's first superfund level project
}

\author{
E. MacLellan \& A. Britten \\ Cape Breton University, Sydney, Canada
}

\begin{abstract}
The paper traces the history of the Sydney Tar Ponds Clean-Up project from the first announcement in 1986 to the present, including comments on the more than $\$ 560 \mathrm{M}$ (USD) spent or committed to date. During this period the project generated thousands of headlines in print, television and radio media; and created significant grief for the community, elected officials, public servants, consultants and others. This paper examines the different attempts to clean-up the tar ponds and scopes out lessons learned related to organization structure, public engagement, risk communication, innovation and other areas.
\end{abstract}

Keywords: Sydney tar ponds, hazardous waste, PAH, PCB, risk communication.

\section{Introduction}

Canada's first superfund level project is on budget and on schedule but the road to this point has had many twists and turns. In 1986 the Government of Canada and Province of Nova Scotia announced the Sydney Tar Ponds Clean-up project with a total budget of \$34M; but from 1986 to 2010 there has been at least $\$ 560 \mathrm{M}$ spent or committed. This paper will provide background on the turbulent history of the project in four distinct stages. The lessons learned are then highlighted for discussion.

\section{The community in history}

The Tar Ponds and Coke Ovens sites (Figure 1) are a legacy of a steel and coal industry that goes back to the Dominion Iron \& Steel Company in 1899. The attraction for establishing a coal industry in Cape Breton was the coal mines, a very good harbour and the proximity to markets. In 1920 the British Empire 
Steel Corporation (BESCO) purchased the assets and continued operations. The Financial Times of Canada commented on the corporate citizenship of BESCO in an article entitled "Firm From Hell" where they stated: "The British Empire Steel Corporation (BESCO) was the wickedest company in Canadian history". [1] BESCO was eventually purchased by the Dominion Steel and Coal Company (DOSCO) and later Hawker-Siddley who in 1967 announced closure of the plant. The day was known as Black Friday.

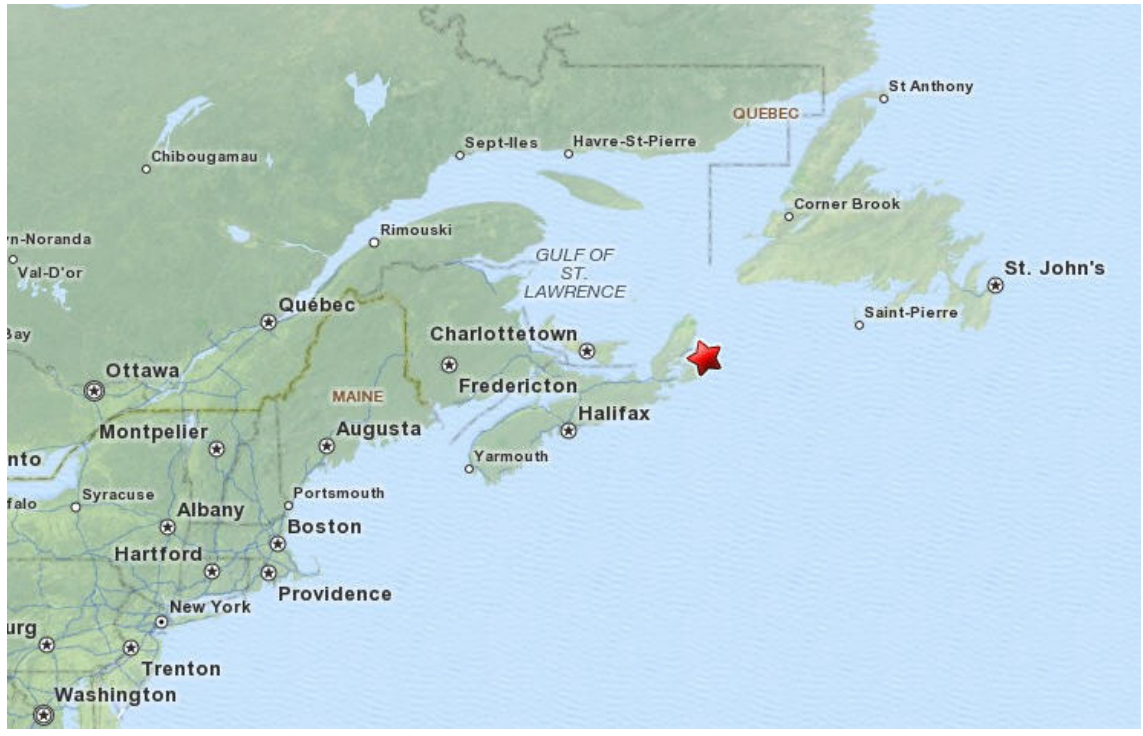

Figure 1: Location (star) of the Sydney tar ponds, Sydney, Nova Scotia, Canada.

The Province of Nova Scotia stepped up to the plate and purchased the assets and subsidized operations under the name of Sydney Steel Corporation (SYSCO) until closure in 2001. Adjacent to the SYSCO is the Coke Ovens site that operated until 1988. Downwind of the Coke Ovens is a cultural mosaic of second generation immigrants from Poland, Russia, the West Indies, Ukraine and other areas; who were mixed with people from Scotland, France and England. For many years these communities were showered with toxins from the Coke Ovens stack; and blamed for high levels of cancer.

\section{The contaminated site}

The residual from this industrial past are two major hazardous waste sites. The Tar Ponds consist of North and South Pond (Figure 2) and are located between the North End of Sydney peninsula to the west; and SYSCO to the east. A small bridge separates the ponds. Sydney Harbour is located to the west of the North End of Sydney peninsula. 


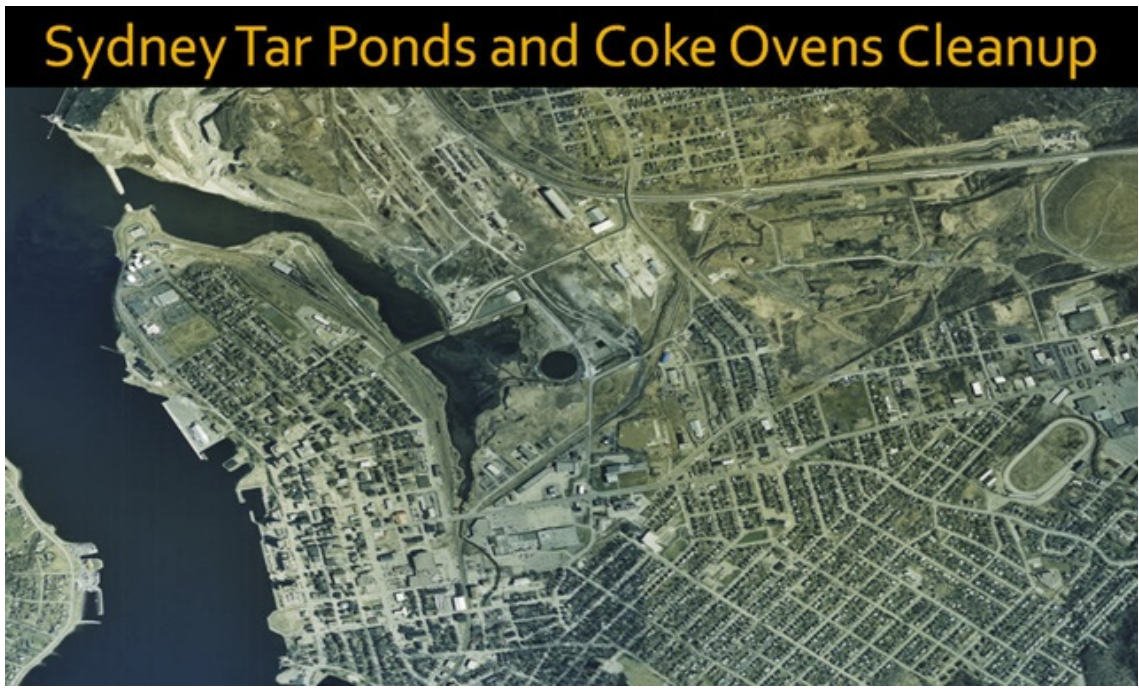

Figure 2: $\quad$ North pond (top); south pond (bottom); Sydney harbour (west, left).

The ponds are about 33 hectares and have about 700,000 tonnes of polycyclic aromatic hydrocarbon (PAH) contaminated material. Much of the contaminated sediments have PAH concentrations of 6000 to $7000 \mathrm{mg} / \mathrm{kg}$; which is well above Canadian Council of Ministers of Environment (CCME) guidelines. About 5\% of the marine sediments are also contaminated with polychlorinated biphenyls (PCB) ranging from a few hundred parts-per-million (ppm) to some areas with a few thousand ppm. The CCME limit for PCB is $50 \mathrm{ppm}$. There are also metals in the mix at levels above those allowed by CCME. This site presents a major problem for three reasons: a) it is located in a tidal zone and includes two brooks, b) the site is adjacent to a residential community and c) the volume of contaminated material is 700,000 tonnes.

Adjacent to the SYSCO property is a property that was operated by the Coke Ovens. Since the decommissioning and removal of the Coke Ovens infrastructure, the site is left with a residual cocktail of contaminated sediments. This property is about 72 ha and has 300,000 tonnes of PAH and VOC contaminated material. The Coke Ovens also had a tar cell holding 25,000 tonnes of coal tar [2-4].

\section{The incineration announcement in $\mathbf{1 9 8 6}$}

In 1986, the Government of Canada and Province of Nova Scotia announced a $\$ 34.2 \mathrm{M}$ excavation and incineration project to clean up the Tar Ponds property. The low cost of the excavation and incineration project was due anticipated revenue from power sales. The justification for the project was environment; and was due to the PAH contaminated sediments continuously discharging to the harbour at levels well beyond those allowed by the CCME. The project elements 
consisted of a specially manufactured dredge, a pipeline from the North and South Ponds to the fluidized bed incinerator, and co-generation. [3] The incinerator was regrettably located adjacent to an existing generator that was about a mile from North and South Ponds, increasing the cost and complexity of materials handling.

The project organization structure was a Federal (70\%) and Provincial (30\%) Management Committee, consultants, and a dysfunctional citizens' liaison committee. The government committee was involved in day to day operations and were responsible for the major technical, financial and other decisions; hence, liability was reduced for the private sector.

In 1991 the Government of Canada moved responsibility to the Province and stepped down from the clean-up project. A Provincial crown corporation, Sydney Tar Ponds Clean-Up Incorporated with a local Board of Directors, was established to operate the completed facility. For the next few years the Province struggled to commission the dredge, pipeline, incinerator and other components of the project. While the incinerator met the compliance tests in 1994 and therefore the contractor was paid, the operation costs were much higher than that originally estimated in the design documents. The materials handling system included a specially designed Mudcat dredge unit and one mile of pipeline; but it did not work. The productivity of dredging, pumping through the pipeline and incineration was about $5 \%$ of the originally estimated throughputs. Out of desperation, in 1996 the Province decided to terminate contracts and open a new call for proposals that would consider both excavation/ incineration, containment and other technologies. For the 1986-1996 period, more than $\$ 100 \mathrm{M}$ was spent on the project.

\section{The second try -1996}

The international call for proposals attracted significant interest and resulted in two competing options: a) excavation and incineration for a cost of $\$ 160 \mathrm{M}$ (i.e. $\$ 160 \mathrm{M}$ in addition to the $\$ 100 \mathrm{M}$ already spent) or b) containment at about \$30M. The Coke Ovens clean-up and Environmental Impact Assessment (EIA) costs would be in addition to these amounts. The Province abandoned the excavation and incineration option and selected containment as the preferred go forward plan.

The national media representing television, printed press, radio and others kept the cross-hairs on the project. While there was attention given to the file in earlier years it now escalated. All public meetings now involved excessive levels of outrage and frustration. When the corporation registered the proposed containment project for an environmental assessment; and also surprisingly found about 45,000 tonnes of PCB contaminated sediments (i.e. 45,000 tonnes of PAH contaminated sediments that also contained more than $50 \mathrm{ppm}$ of $\mathrm{PCB}$ ) the process came to a standstill. The political fallout was too much of a burden and the political masters abandoned the containment option and contemplated a new direction. 


\section{An experiment in public consultation - 1996}

The Third Try to clean-up the Tar Ponds involved a large, complex, unstructured public consultation program known as the Joint Advisory Group (JAG) process; which over a period of seven years conducted more than 900 public meetings. The level of effort for committee members was exhausting and often required lengthy, weekly meetings. The committees were searching for complex, "made in Cape Breton" technical solutions while having minimal scientific or engineering capacity. The meetings were stormy and public sessions sometimes required police security. This process bled the community and deflected the spotlight from political representatives, government officials and consultants; to voluntary committee members. While there was technical support for some of their tasks it is fair to say that many of the committees wandered aimlessly. The JAG team also claimed to be following the steps of the environmental assessment process and would in the end, save time for the clean-up project; but this did not happen.

In 2003 the JAG group presented their final report to government. The JAG committee recommended excavation and offsite incineration at a Nova Scotia Power plant at Point Aconi, about $40 \mathrm{~km}$ from the site. Neither Nova Scotia Power nor the community of Point Aconi wanted any involvement in the project. Also, the lengthy distance from the Tar Ponds site to Point Aconi meant very high materials handling costs, in addition to the problems associated with trucking hazardous waste through communities. Before the ink was dry on their report, the government abandoned the suggestion and instead decided on solidification and stabilization. This evolvement of the project resulted in a fourth and final attempt to clean-up the site. During this period the Auditor General of Canada had an interest in the project [5].

\section{The fourth attempt}

Up to this point the government spent more than $\$ 100 \mathrm{M}$ on excavation and incineration, \$62M for a bundle of studies for the 1999 to 2004 period, a few million for JAG operations, plus having to meet other fiscal obligations. In 2004 the Government of Canada and the Province of Nova Scotia announced a \$300M PAH Solidification and Stabilization project and a \$100M PCB incineration project, totalling $\$ 400 \mathrm{M}$.

If there was public objection to the PCB incineration component of the work, the PCB project defaulted to solidification and stabilization of PCB. The government's preference for proposing PCB incineration first and PCB solidification and stabilization second, was driven by Government of Canada policy having this priority. The project was registered for an environmental assessment and in 2005 the Minister announced a full environmental assessment panel. The full panel requires extensive public consultation and for many in the community, this was a surprise because the JAG process conducted more than 900 public meetings. 
The EIA panel dropped the plan for PCB incineration and required other adjustments in the project definition; but otherwise gave the project their blessings to proceed. Essentially, metals, PCB, PAH and other contaminants would be treated in place by Solidification and Stabilization of the cooling pond and the North and South Ponds (Figure 3). Since the announcement the project has been on schedule and has had minimal fallout with the public. The JAG process depleted even the most hostile of opponents.

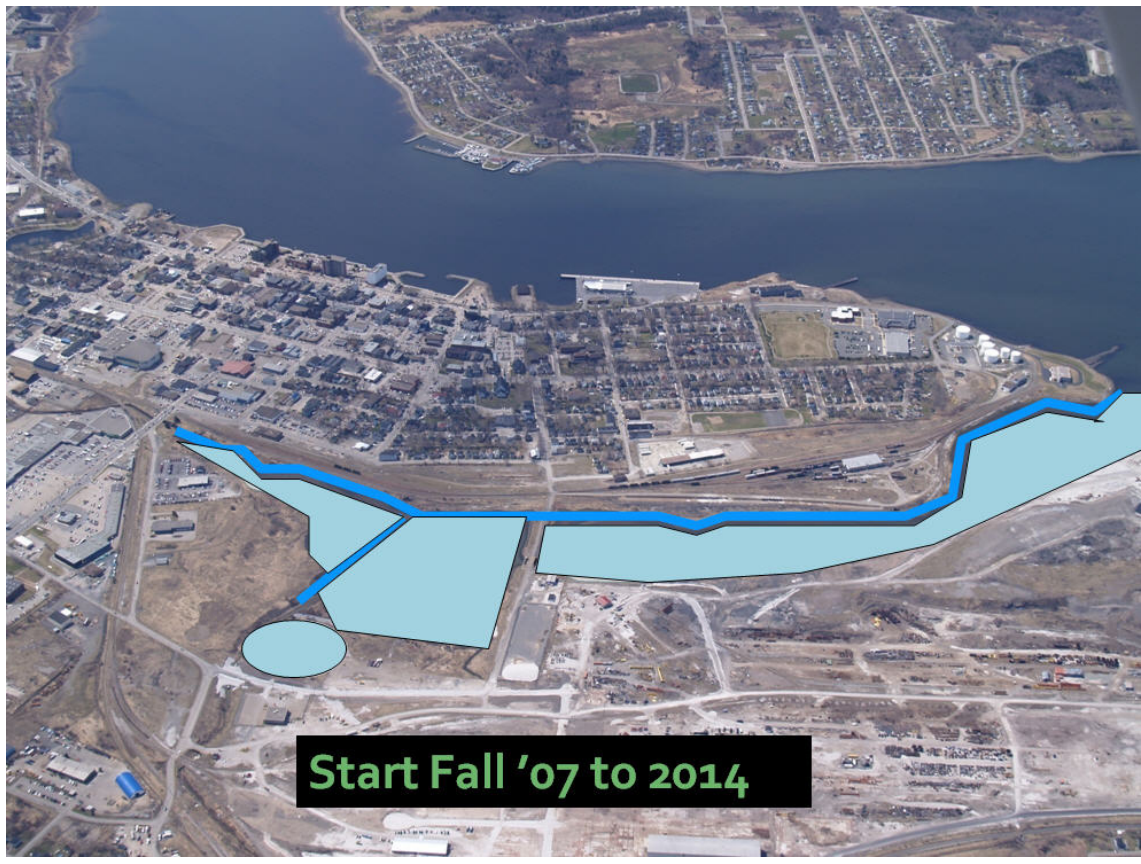

Figure 3: Depiction of solidification and stabilization of the cooling pond (now complete) and the North and South ponds (planned).

The project has a sunset of 2014 by which all work must be complete; otherwise the Province will be forced to continue the work without funding from the Government of Canada.

In the lead at the federal level is Public Works and Government Services Canada (PWGSC); while for the province the lead department is the Nova Scotia Department of Transportation and Infrastructure Renewal. The organization structure for this portion of the work is a five person Federal/ Provincial management committee representing the two lead departments, functioning as an oversight board. They establish policy and monitor the progress of the work in their quarterly meetings. Reporting to the committee is a single purpose, special provincial operating unit, the Sydney Tar Ponds Agency (STPA). This agency has a staff of 20 or more people and is responsible for ensuring that the project is completed on budget and on time; and in a safe manner. STPA have a group of 
consultants who are responsible for the major technical decisions. In addition, they have an independent engineer who provides the owner with independent advice on all aspects of the project including studies, design, contract administration, health and safety and other areas. The independent engineer team will have professional fees in the order of $\$ 15 \mathrm{M}$, hence, their oversight service is a substantial component of the project. This phase of the project also has a Citizen's Liaison committee. The committee members are appointed by the project to represent community institutions, e.g. there are representatives from the municipality, health organizations, the local university, and others. The committee functions well and has been an effective sounding board for the community. All indications are that the project will be successfully completed by the March 2014 target date.

\section{Discussion}

In the discussion there are four themes identified including:

- Project organizational structure;

- Public engagement;

- Risk communication; and

- Innovation.

Large, complex projects should design a governance structure that suits the goals of the project. Because the initiative is entirely funded by two levels of government, this necessitates a need for public service representation to ensure compliance with federal and provincial policies, in addition to the need to monitor, evaluate and manage contracts. The organization structure should also allow the private sector's consultants and contractors to do their work and offer the best value service for the available budget, however, there should be professional liability attached to these contracts. In addition, the project team must also be engaged with communities because they are the major stakeholders. The community and local government institutions must have the opportunity to communicate their concerns and be confident that the work is done to their satisfaction.

In 1986 Environment Canada, the country's lead federal environmental regulator was also acting as the lead clean-up proponent. Environment Canada partnered with the Province of Nova Scotia in a 70/30 arrangement and had significant involvement in the design of the project. Although there were substantial sums of money spent on consultants, there was no clear division of responsibilities between government and the private sector. When this block of work was abandoned in 1996; there was more than \$100M of taxpayer's money spent. Because the project organization structure tipped the day to day technical decisions away from the private sector, there was little or no liability for the private firms. This organizational structure had serious challenges.

At the other extreme, the JAG structure mandated a roundtable and hundreds of volunteers to take command of the project and search for solutions to a complicated problem. The JAG group consisted of mostly sincere volunteers but 
had little to no capacity to fulfil its mandate. Following seven years of work involving more than 900 meetings and about 100,000 hours of volunteers' time, their recommendations were presented to government but were not accepted. The JAG process drained the energy out of volunteers, created unrealistic expectations and often had challenges controlling outrage at meetings.

The JAG process deviated from other successful public participation programs. JAG had lengthy, weekly meetings; which is a level of commitment that excludes a major component of the volunteer sector. Successful public engagement programs typically have monthly or quarterly meetings. Other successful public engagement programs also have a well defined project to focus the public's attention. In contrast, JAG was open ended and ill defined. For example, the full Environmental Assessment Panel required a public participation program focused on the definition of the project. The 900 JAG meetings lacked this focus and did not qualify as the public involvement for an EIA.

The project organization structure and public engagement are intertwined. If the community involvement is within a terms of reference that is too narrow, it will not work. If the involvement is within a terms of reference that is too broad and ill defined, it also will not work. The design of the engagement program must also not burn out volunteers. The JAG model was weighted with problems that were more attributed to the program's structure; than the many, sincere volunteers.

The other two lead organization structures involved the Sydney Tar Ponds Clean-Up Corporation ( $2^{\text {nd }}$ attempt) and the Sydney Tar Ponds Agency (4 ${ }^{\text {th }}$ attempt). The advantage of the agency over the government corporation is that it allows technical people in government to be more insulated from political interference. However, the government corporation could also be a useful model. The Sydney Clean-Up Corporation was given the keys to a dredge, pipeline and incinerator system that operated at about $5 \%$ of the designed production level. This, in addition to finding 45,000 tonnes of PCB contaminated sediments that were not known to be on the North and South Pond site, was an excessive burden to the organization. STPA had a lead role during a calmer period and encountered little difficulty with the Solidification and Stabilization proposal. However, both the corporation and special operating agency were single purpose institutions that are appropriate for this type of project.

A third important theme for further discussion is risk communication, which is a challenge on nearly all superfund level projects. Risk was a central theme for the vast majority of community consultations and presents a problem that has been difficult to manage. A scientific definition of health risk, for example, is a hazard + pathway + receptor $=$ risk.

If a situation is missing either a hazard, pathway or receptor; then there is no risk. The public and media often equate risk with hazards. The risk theme was also explored on Sydney Tar Ponds by others (Haalboom et al. [6]). Compounding this is the problem of degrees of risk. Science profiles risk on a continuum whereas the public and media often have a $0 / 1$, i.e. the person has no risk or becomes very ill. Risk communication is a serious issue on most large 
hazardous waste projects. While some progress has been made, there is much more work to do [6-8].

A fourth theme of some importance is innovation. A project valued at more than $\$ 560 \mathrm{M}$ is expected to advance the state of the art in sampling and analytical procedures, materials handling, remediation technology, or in other areas. On the Tar Ponds project there have been only nominal benefits related to innovation, in part due to the minimal involvement of university researchers. To a significant extent this was linked to the troubled history of the project; but is also connected to the requirement to follow established standard testing and remediation methods.

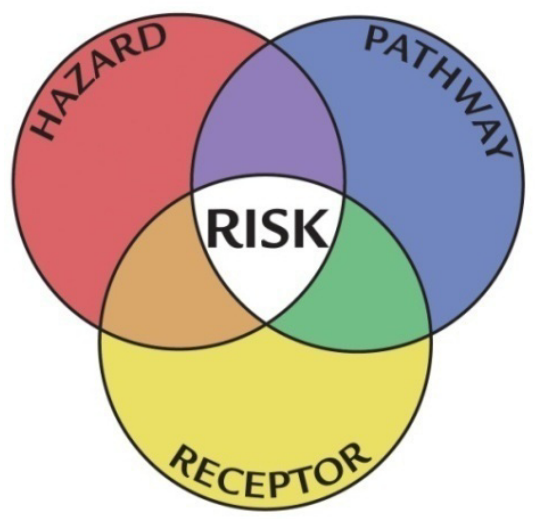

Figure 4: Components of health risk.

\section{Conclusions}

An overarching conclusion from the Sydney Tar Ponds Clean-Up project is the need for pollution prevention. The project is a good illustration of the massive end-of-pipe costs associated with these problems.

The work on the Tar Ponds project is relevant internationally for a number of reasons. The global shift from heavy industrial economic activities to a knowledge based economy has resulted in many closed industrial sites. Often these sites have problems in their backyards and require major efforts to manage risks. Also, these properties usually have absent or bankrupt polluters and the taxpayers and community are left responsible for costs.

Another dimension of this project that is relevant for clean-ups in other areas is better understanding the relationship between the project investment, and the reduced risk benefits for human health and the environment. Once a government makes a commitment of millions of dollars for air quality monitoring, for example, it may not be willing to reduce or withdraw the investment even after significantly reduced environmental risk. Too much investment for modest levels of risk reduction wastes resources, while too little investment for reducing 
significant human health and environment risks has consequences. Our global community continues to search for the balance.

\section{References}

[1] Financial Times of Canada. Firm from Hell. November 7, 1992, p. 2 in a Special $80^{\text {th }}$ Anniversary Edition, Toronto.

[2] ACRES International Ltd. 1991, "Sydney Tar Pond Study: Final Report to the Nova Scotia Department of Environment" (3 Volumes), Halifax, Nova Scotia

[3] Travers, I.C. and Hill, I.K., 1991, "The Sydney Tar Ponds Clean-up Project" an unpublished paper presented to the Annual Hazardous Materials Management Conference, Toronto.

[4] AMEC Earth \& Environmental, 2004, "Remediation of the Sydney Tar Ponds and Coke Ovens Sites", unpublished report.

[5] Auditor General of Canada, 2002, "Report of the Commissioner of the Environment and Sustainable Development, unpublished report.

[6] Haalboom, Bethany; Elliot, Susan; Eyles, John; Muggah, Henry. The Risk Society at Work in the Sydney "Tar Ponds". Canadian Geographic, 50 (2), pp. 227,2006

[7] Hance, BJ; Chess, Caron and Sandman, Peter, Industry Risk Communication Manual: Improving Dialogue with Communities, Boca Raton, Lewis Publishers. 1990.

[8] Sandman, Peter, 1986, "Explaining Environmental Risk: Some Notes on Environmental Risk Communication", Washington, D.C., Environmental Protection Agency. 